\title{
Pemodelan TEC Regional dari Data GPS Stasiun Tetap di Indonesia dan Sekitarnya
}

\author{
Buldan Muslim ${ }^{1,2)}$, Hasanuddin Z. Abidin ${ }^{2)}$, The Houw Liong ${ }^{3)}$, Wedyanto \\ Kuntjoro $^{2)}$, Cecep Subarya ${ }^{4)}$, Heri Andreas ${ }^{2)} \&$ M. Gamal ${ }^{2)}$ \\ ${ }^{1)}$ Kelompok Dinamika Atmosfer Atas, Bidang Ionosfer dan Telekomunikasi \\ Pusat Pemanfaatan Sains Antariksa, LAPAN, Jl. Dr. Junjunan 133 Bandung 40173 \\ ${ }^{2)}$ Kelompok Keahlian Geodesi dan Geomatika, Program Studi Teknik Geodesi \\ Fakultas Teknik dan Linkungan, Institut Teknologi Bandung, Jl. Ganesha 10 Bandung \\ ${ }^{3)}$ Program Studi Fisika, Fakultas Matematika dan Ilmi Pengetahuan Alam \\ Institut Teknologi Bandung, Jl. Ganesha 10 Bandung \\ 4) Bidang Geodinamika, Pusat Geodesi dan Geodinamika, Badan Koordinasi Survei dan \\ Pemetaan Nasional, Jl. Raya Jakarta - Bogor Km 46, Cibinong 16911
}

\begin{abstract}
Abstrak. Ionosfer mempengaruhi gelombang elektromagnetik yang melewati lapisan tersebut dengan menginduksi suatu tambahan waktu tunda transmisi. Dalam penentuan posisi dan navigasi dengan GPS, gangguan ionosfer telah menjadi sumber kesalahan terbesar setelah kesalahan yang bersumber dari Selective Availability (SA) tidak diaktifkan. Untuk penentuan posisi presisi tinggi dengan GPS pengaruh ionosfer harus diestimasi sehingga koreksi ionosfer dapat ditentukan untuk mengeliminasi pengaruh ionosfer pada pengamatan GPS. Dalam penetuan posisi dengan GPS frekuensi tunggal koreksi ionosfer dapat diperoleh dari TEC yang dihitung dari data GPS dual frekuensi stasiun referensi atau dari model. Makalah ini menjelaskan metode penentuan dan pemodelan TEC dari data GPS stasiun tetap yang ada di Indonesia dan sekitarnya. Model TEC spasial pada jam tertentu diestimasi menggunakan fungsi polinom. Variasi diurnal koefisien model polinom pada setiap jam mulai pukul $00.00-23.00$ UT diestimasi menggunakan ekspansi Fourier.
\end{abstract}

Kata kunci: GPS; bias ionosfer; kombinasi kode dan fase; total electron content; kalibrasi; model; regional.

\begin{abstract}
Ionosphere affect propagation of electromagnetic waves through it by adding a transmission delay time. In GPS positioning and navigation, ionospheric delay is largest source of error after error from Selective Availability (SA) was turned off. For GPS positioning precisely ionospheric effect must be estimated so ionospheric correction can be determinated to eliminate ionospheric effect on GPS observation. In positioning by using GPS single frequency, ionospheric correction can be obtained from GPS dual frequency receiver at reference station or model. This paper describes method of determination and modeling of regional total electron content (TEC) from continuous GPS station in Indonesia and it's around. Spatial model of TEC at certain time is estimated
\end{abstract}


by using polynomial function. Diurnal variation of polynomial model coefficient at certain hour from $00.00-23.00$ UT is estimated with Fourier expansion.

Keywords: Regional; model; calibration; total electron content; code and phase combination; ionospheric bias and GPS.

\section{$1 \quad$ Pendahuluan}

Ionosfer mempengaruhi gelombang elektromagnetik yang menjalar melalui lapisan tersebut berupa tambahan waktu tunda propagasi. Besar pengaruh tersebut ditentukan oleh kandungan elektron total (total electron content, TEC) dan frekuensi gelombang elektromagnetik yang digunakan. TEC adalah kandungan elektron total dalam suatu silinder berpenampang 1 meter persegi yang panjangnya sama dengan jarak dari satelit ke penerima GPS. Dalam kondisi normal pengaruh ionosfer pada sinyal GPS berkisar antara beberapa meter sampai beberapa puluh meter. Pada saat badai ionosfer bias ionosfer dapat mencapai 100 meter atau lebih. Setelah Selective Availability (SA) atau kesalahan yang sengaja ditambahkan pada data kode untuk seleksi atau pembatasan akurasi data GPS pada pengguna tertentu sudah tidak diaktifkan maka pengaruh ionosfer menjadi sumber kesalahan yang terbesar dalam penentuan posisi dan navigasi GPS. Untuk mendapatkan penentuan posisi dengan presisi yang tinggi kesalahan yang bersumber dari ionosfer harus diestimasi agar dapat dieliminir dalam pengamatan GPS. Estimasi pengaruh ionosfer juga penting untuk penelitian cuaca antariksa dan aplikasi pengamatan bumi dari satelit, penelitian prekursor gempa bumi melalui ionosfer, irregularitas ionosfer dan proses kopling atmosfer-ionosfer melalui gelombang gravitasi atau medan listrik.

Untuk mengatasi pengaruh ionosfer pada sinyal GPS, beberapa metode pemodelan ionosfer telah dikembangkan meliputi model Klobuchar, koreksi frekuensi ganda, metode differensial dan pemodelan jaringan area luas, regional dan lokal. Masing-masing metode tersebut sesuai untuk kondisi dan syaratsyarat tertentu.

Untuk keperluan penentuan posisi absolut, model Klobuchar atau frekuensi ganda dapat digunakan yang tentunya tergantung dari tipe alat penerima sinyal GPS yang digunakan. Model Klobuchar diturunkan secara empiris dari klimatologi ionosfer jangka panjang. Model tersebut dirancang untuk pengguna GPS frekuensi tunggal. Model ini memiliki akurasi sekitar beberapa meter untuk daerah lintang tengah (Klobuchar, 1987). Untuk lintang rendah seperti Indonesia kesalahan model tersebut bisa lebih besar. 
Metode frekuensi ganda memanfaatkan sifat dispersif ionosfer dan diperlukan GPS frekeunsi ganda untuk mengeliminer pengaruh ionosfer. Jika data pengamatan frekuensi ganda sinyal GPS diperoleh, maka data tersebut dapat digunakan untuk mendapatkan estimasi bias ionosfer orde pertama pada sinyal GPS frekuensi tunggal yang kemudian dapat digunakan untuk menghilangkan pengaruh ionosfer.

Differensial GPS (DGPS) adalah metode lain yang dapat digunakan untuk mereduksi pengaruh ionosfer. Walaupun DGPS dapat menghasilkan akuarsi level sentimeter, tetapi metode ini hanya efektif untuk skala lokal dalam jangkauan sekitar $50 \mathrm{~km}$. Untuk skala regional DGPS tidak dapat digunakan. Jika harus digunakan maka dibutuhkan banyak GPS yang harus dioperasikan pada jarak sekitar $50 \mathrm{~km}$, yang tentunya koreksi ionosfer skala regional menggunakan DGPS menjadi tidak efektif. Dengan alasan tersebut Wide Area Differential GPS (WADGPS) dan Regional Area Differensial GPS menjadi semakin banyak digunakan untuk mengatasi keterbatasan metode konvensional DGPS.

WADGPS menggunakan seluruh stasiun referensi dengan garis dasar (baseline) umumnya sekitar ribuan kilometer. Stasiun referensi menggunakan alat penerima GPS frekuensi ganda dan dilengkapi dengan sarana komunikasi data. Dalam kasus ini, ionosfer diamati menggunakan pengamatan GPS dari semua stasiun referensi. Ionosfer diestimasi untuk area tertentu menggunakan beberapa model yang sesuai seperti model berbasis grid, harmonik bola dan fitting polinom (El-Arini et.al., 1994). Penelitian dalam area ini telah dilakukan secara ekstensif dan telah diperoleh akurasi dalam level sub meter untuk kondisi aktifitas matahari minimum.

Dengan semakin bertambahnya stasiun GPS permanen yang dikelola oleh International GPS Services (IGS) yang telah mencakup seluruh permukaan bumi, penelitian ionosfer menggunakan GPS telah mencapai skala global. Jaringan GPS IGS telah menghasilkan data yang telah digunakan oleh pusatpusat analisis IGS untuk menghasilkan produk seperti koreksi ionosfer dan troposfer, orbit GPS presisi, koreksi jam receiver dan satelit yang presisi, dan juga parameter rotasi bumi. Hasil-hasil proses yang berbeda dari pusat-pusat analisis data GPS juga dihimpun untuk analisis lanjut dan untuk studi komparasi.

RADGPS terdiri dari stasiun-stasiun referensi yang terdistribusi secara regional dengan garis dasar umumnya sekitar beberapa ratus kilometer dan dapat digunakan untuk koreksi ionosfer bagi pengguna di daerah tersebut. RADGPS secara konseptual sama dengan WADGPS hanya saja dengan garis dasar lebih 
pendek dan cakupan luas yang lebih kecil serta dengan distribusi stasiun referensi yang lebih rapat.

Untuk daerah terbatas dalam sekala regional, selain dengan metode differensial, koreksi ionosfer juga dapat dilakukan menggunakan model TEC regional. Dengan model TEC regional pengamatan pseodorange atau fase GPS harus dikoreksi terlebih dahulu untuk mereduksi bias ionosfer pada masing-masing gelombang pembawa L1 dan L2 sebelum diproses untuk penentuan posisi.

Makalah ini menjelaskan hasil-hasil penelitian yang ditujukan untuk menjawab pertanyaan berkenaan dengan penentuan dan pemodelan TEC regional dari data GPS sbb:

1. Bagaimana mendapatkan metode/algoritma yang paling cocok untuk penentuan parameter ionosfer dari data GPS di Indonesia dan sekitarnya?

2. Fomulasi seperti apa yang optimum dapat digunakan untuk pemodelan TEC regional Indonesia?

\section{Data dan Metode}

Data yang telah digunakan dalam penentuan dan pemodelan TEC regional bersumber dari data pengamatan GPS stasiun tetap yang dioperasikan oleh beberapa pengelola sebagaimana ditunjukkan pada Tabel 1. Data GPS yang diperoleh dari beberapa stasiun tetap sebagaimana terlihat pada tabel tersebut dikelola oleh beberapa instansi yang berbeda dan periode pengamatannya juga berbeda-beda. Adapun distribusi penerima GPS di wilayah Indonesia dan sekitarnya dapat dilihat pada Gambar 1.

Tabel 1 Lokasi GPS receiver yang akan digunakan dalam pemodelan ionosfer.

\begin{tabular}{|l|l|l|l|}
\hline No & Kode & Lokasi Stasiun Pengamatan & Pengelola / Sumber data \\
\hline 1 & SAMP & Sampali & Bakosurtanal \\
\hline 2 & NTUS & Singapura & IGS-Singapura \\
\hline 3 & COCO & Cocos Island & IGS-Australia \\
\hline 4 & BAKO & Cibinong & Bakosurtanal \\
\hline 5 & KOEP & Kupang & Bakosurtanal \\
\hline 6 & PARE & Parepare & LAPAN-Bakosurtanal \\
\hline 7 & TOLI & Toli-toli & Bakosurtanal \\
\hline 8 & PIMO & Filipina & IGS-Filipina \\
\hline 9 & DARW & Darwin & IGS-Austarlia \\
\hline 10 & BIKL & Biak & LAPAN-Bakosurtanal \\
\hline 11 & LAE1 & Lae, Vanimo & IGS \\
\hline
\end{tabular}




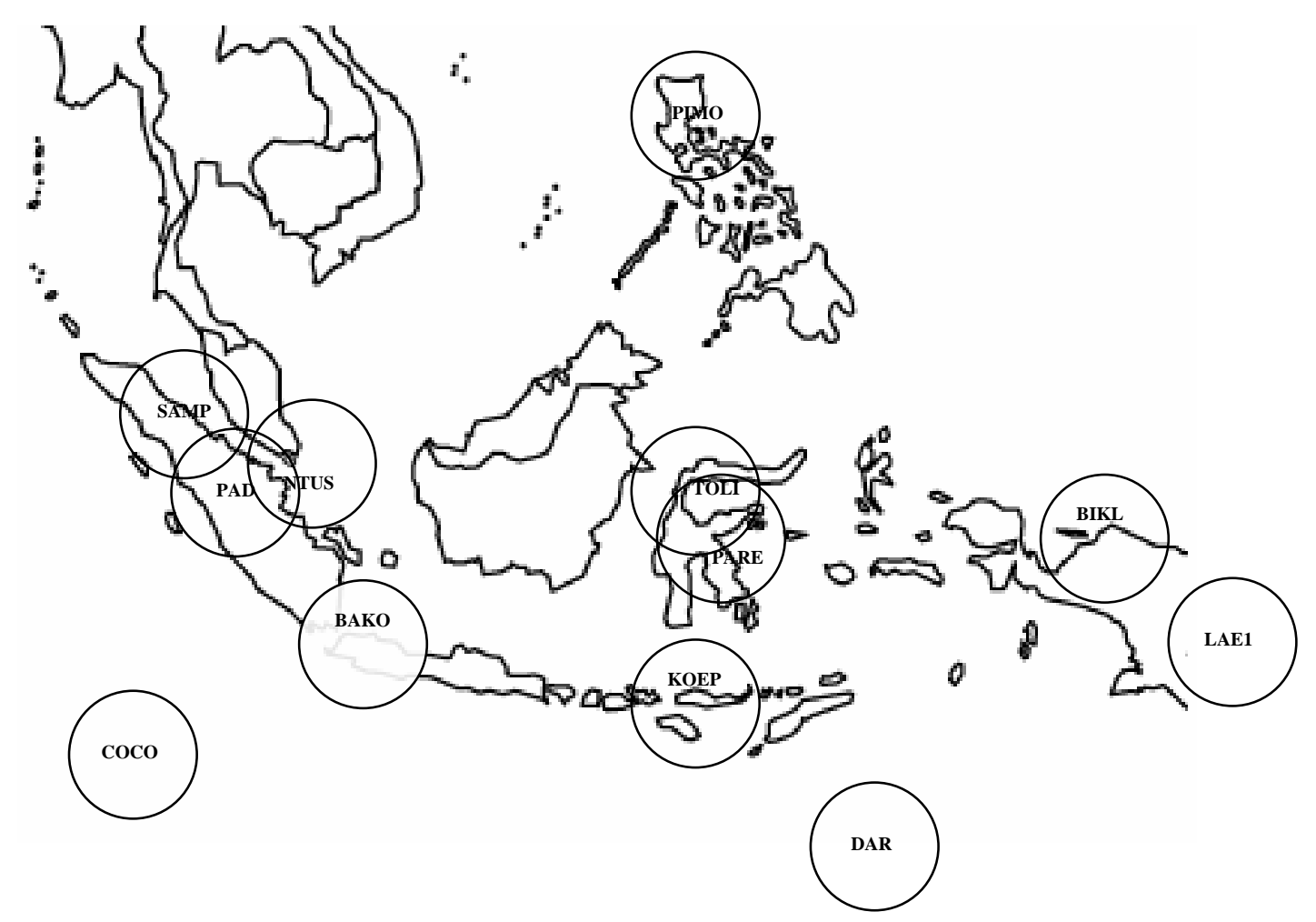

Gambar 1 Distribusi lokasi stasiun pengamatan sinyal GPS di Indonesia dan sekitarnya.

\subsection{Penentuan TEC Menggunakan Data Kode}

Penerima sinyal GPS frekuensi ganda yang digunakan di stasiun referensi berisi pengamatan kode dan fase pada frekuensi L1 (1575.42 MHz) dan L2 (1227.60 $\mathrm{MHz})$ yang dinotasikan dengan $P_{\mathrm{i}}$ dan $\Phi_{\mathrm{i}}(\mathrm{i}=1,2)$. Secara matematik pengamatan-pengamatan tersebut dapat diuraikan sebagai berikut (Gao dkk., 2002, dengan sedikit perubahan notasi)

Untuk frekuensi Li, i = 1 dan 2:

$$
\begin{aligned}
& P_{i}=\rho+c(d t-d T)+d_{\text {orb }}+d_{\text {trop }}+I_{i}+b_{P_{i}}-B_{P_{i}}+d_{m / p i}+\varepsilon\left(_{P i}\right) \\
& \Phi_{i}=\rho+c(d t-d T)+\lambda_{i} N_{i}+d_{\text {orb }}+d_{\text {trop }}-I_{i}+b_{\Phi_{i}}-B_{\Phi_{i}}+d_{m / \Phi i}+\varepsilon\left(_{\Phi i}\right)
\end{aligned}
$$

di mana: 
$\rho$ adalah jarak geometri sebenarnya antara satelit dan penerima (m), c adalah kecepatan cahaya $(\mathrm{m} / \mathrm{s})$, $d t$ adalah kesalahan jam satelit terhadap waktu GPS (s), $d T$ adalah kesalahan jam penerima terhadap waktu GPS (s), $\lambda_{i}$ adalah panjang gelombang sinyal GPS pada frekuensi $\mathrm{L}_{\mathrm{i}}(\mathrm{m})$, $N_{i}$ adalah ambiguitas integer fase gelombang pembawa $\mathrm{L}_{\mathrm{i}}$ (siklus), $d_{\text {trop }}$ adalah waktu tunda troposfer (m),

$I_{i}$ adalah parameter waktu tunda ionosfer pada frekuensi $\mathrm{L}_{i}(\mathrm{~m})$,

$d_{\text {orb }}$ adalah kesalahan orbit satelit (m),

$d_{m}$ adalah efek multipath (m),

$b$ adalah waktu tunda hardware satelit (m),

$B$ adalah waktu tunda hardware penerima (m), $\varepsilon$ adalah noise pengukuran (m).

Pengurangan pengamatan jarak kode dari L2 dan L1 menghasilkan pengamatan ionosfer sebagai berikut

$$
P_{2}-P_{1}=I_{2}-I_{1}+\left(b_{p 2}-b_{p 1}\right)-\left(B_{p 2}-B_{p 1}\right)+\varepsilon\left(P_{2}-P_{1}\right)+d_{m / p 2}-d_{m / p 1}
$$

Dengan mendefinsikan $M=d_{m / p 2}-d_{m / p 1}, b=b_{p 2}-b_{p 1}, B=B_{p 2}-B_{p 1}$ yang masing-masing adalah perbedaan waktu tunda hardware antara L1 dan L2 untuk satelit dan penerima, dan sering disebut sebagai bias antar frekuensi L1/L2 satelit dan bias antar frekuensi L1/L2 penerima, dan $I=I_{2}-I_{1}$ adalah perbedaan waktu tunda ionosfer antara frekuensi L2 dan L1, persamaan (3) dapat ditulis sebagai

$$
P_{2}-P_{1}=I+b-B+\varepsilon\left(P_{2}-P_{1}\right)+M
$$

Hubungan antara beda waktu tunda ionosfer $I$ dengan kandungan elektron total sepanjang lintasan dari satelit ke receiver dengan hanya memperhitungkan indek bias orde 1 saja dapat diungkapkan sebagai

$$
I \approx 40.3 \operatorname{STEC}\left(\frac{1}{f_{2}^{2}}-\frac{1}{f_{1}^{2}}\right)
$$

Dengan memasukkan nilai frekuensi pada L1 dan L2 dan membagi dengan $10^{-16}$ dapat diperoleh hubungan beda waktu tunda ionosfer dengan STEC dalam satuan TECU sebagai berikut

$$
I=0.105 S T E C
$$


Sehingga persamaan (4) dapat ditulis sebagai

$$
Y=\alpha S T E C+C
$$

dengan $Y=P_{2}-P_{1} \quad \alpha=0.105$ dan

$$
C=b-B+\varepsilon\left(P_{2}-P_{1}\right)+M
$$

\subsection{Penentuan TEC dari Kombinasi Data Kode dan Fase}

Pengurangan pengamatan jarak fase ( $\Phi_{i}=\lambda_{i} \phi_{i}$ ) pada pengamatan gelombang pembawa L1 dan L2 dapat menghasilkan

$$
\Phi_{2}-\Phi_{1}=I_{2}-I_{1}+\left(b_{p 2}-b_{p 1}\right)-\left(B_{p 2}-B_{p 1}\right)+\varepsilon\left(P_{2}-P_{1}\right)+\lambda_{2} N_{2}-\lambda_{1} N_{1}
$$

Dengan cara yang sama pada pengamatan kode pengurangan persamaan pengamatan jarak fase tersebut dapat diringkas menjadi

$$
\Phi_{2}-\Phi_{1}=I+b-B+\varepsilon\left(P_{2}-P_{1}\right)+\lambda_{2} N_{2}-\lambda_{1} N_{1}
$$

Persamaan (7) masih mengandung siklus ambiguitas $N_{i}$ yang harus diselesaikan jika akan dihitung bias ionosfer langsung dari persamaan tersebut. Tetapi jika tidak ada cycle slip pengamatan jarak fase pada waktu pengamatan ke $k$ nilai $N_{i}$ tetap. Maka dengan pengurangan jarak fase pada waktu pengamatan ke $k$ dengan jarak fase epok ke $k-1$ persamaan (7) menjadi

$$
\left(\Phi_{2 k}-\Phi_{2 k-1}\right)-\left(\Phi_{1 k}-\Phi_{1 k-1}\right)=I_{k}-I_{k-1}
$$

Dan hubungannya dengan perbedaan STEC pada waktu pengamatan ke $k$ terhadap STEC waktu pengamatan ke $k-1$ adalah

$$
\left(\Phi_{2 k}-\Phi_{2 k-1}\right)-\left(\Phi_{1 k}-\Phi_{1 k-1}\right)=0.105\left(S T E C_{k}-S T E C_{k-1}\right)
$$

yang dapat diringkas menjadi

$$
\Delta S T E C_{k / k-1}=9.524\left(\Delta \Phi_{2 k / k-1}-\Delta \Phi_{1 k / k-1}\right)
$$

Dengan diperolehnya beda STEC antar waktu pengamatan dari data fase, maka jika nilai awal STEC sudah ditentukan dari data kode, nilai selanjutnya dapat diperoleh dengan menjumlahkan STEC nilai awal dengan beda STEC antar epok. Dengan demikian dapat dipeoleh nilai STEC absolut yang penentuannya diperoleh dari kombinasi data kode (untuk penentuan STEC awal) dan data fase (untuk penentuan beda STEC antar waktu pengamatan). Perumusan penentuan STEC kombinasi data kode dan fase dengan cara ini dapat dituliskan sebagai 


$$
S T E C_{k}(k o d e+\text { fase })=S T E C_{0}(\text { kode })+\Delta S T E C_{k}(\text { fase })
$$

Yang dapat juga ditulis menjadi (dengan substitusi)

$$
S T E C_{k}(k o d e+\text { fase })=9.524\left\{\left(P_{2}-P_{1}\right)_{0}+\Delta \Phi_{2 k}-\Delta \Phi_{1 k}\right\}
$$

Selain dengan penggunaan data TEC kode sebagai nilai awal, kombinasi data kode dan fase untuk penentuan TEC bisa juga dilakukan dengan metode yang biasa disebut sebagai penghalusan TEC kode dengan TEC fase atau pelevelan fase (phase leveling). Metode ini diuraikan sebagai berikut.

Dengan data pengamatan jarak kode satelit GPS kita dapat menghitung TEC dengan persamaan (Liu Z., 2004)

$$
\operatorname{STEC}_{k}=\frac{f_{1}^{2}\left[\left(P_{1}-P_{2}\right)-B_{i}-B^{p}\right]}{40.3(1-\gamma)}
$$

Dengan $P_{1}$ adalah pengamatan jarak kode satelit GPS pada frekuensi $\mathrm{L}_{1}$ (1.575.42 $\mathrm{GHz}$ ) dan $P_{2}$ adalah pengamatan jarak kode satelit GPS pada frekuensi $\mathrm{L}_{2}(1.227 .6 \mathrm{GHz}), B_{i}$ adalah bias differensial pengamatan jarak kode untuk alat penerima dan $B^{p}$ adalah bias differensial pengamatan kode untuk satelit. $f_{1}$ adalah frekuensi gelombang pembawa pada L1 dan $\gamma$ adalah perbandingan frekuensi pada L1 dengan frekuensi pada L2 $\left(f_{1} / f_{2}\right)$.

Dari data pengamatan jarak fase satelit GPS juga dapat dihitung TEC fase $\left(\mathrm{TEC}_{\Phi}\right)$ sebagai berikut

$$
\operatorname{STEC}_{\Phi}=\frac{f_{1}^{2}\left[\left(\lambda_{1} \Phi_{1}-\lambda_{2} \Phi_{2}\right)-\left(\lambda_{1} N_{1}-\lambda_{2} N_{2}\right)-b_{i}-b^{p}\right]}{40.3(1-\gamma)}
$$

Dengan $\Phi_{1}$ adalah pengamatan jarak fase satelit GPS pada frekuensi $\mathrm{L}_{1}$ dan $\Phi_{2}$ adalah pengamatan jarak fase satelit GPS pada frekuensi $L_{2} . \lambda_{1}$ panjang gelombang padfa frekeunsi $\mathrm{L}_{1}$ dan $\lambda_{2}$ panjang gelombang pada frekuensi pada $\mathrm{L}_{2} . N$ adalah jumlah siklus ambiguitas yang tidak diketahui, $b_{\mathrm{i}}$ dan $b^{p}$ adalah bias diferensial pengamatan jarak fase untuk penerima dan satelit masingmasing.

Pengurangan persamaan (11) dengan (12) menghasilkan perbedaan antara TEC kode dan TEC fase nsebagai berikut:

$$
\Delta T E C_{n}=T E C_{k}-T E C_{\Phi},
$$


yang dengan substitusi akan diperoleh persamaan yang setelah disusun kembali menjadi

$$
\Delta T E C_{n}=\frac{f_{1}^{2}\left[\left(P_{1}-P_{2}\right)-B_{i}-B^{P}+\left(\lambda_{1} \Phi_{1}-\lambda_{2} \Phi_{2}\right)\right]}{40.3(1-\gamma)}+\frac{f_{1}^{2}\left[-\left(\lambda_{1} N_{1}-\lambda_{2} N_{2}\right)-b_{i}-b^{p}\right]}{40.3(1-\gamma)}
$$

Secara teori nilai $\triangle$ TEC ini tetap selama periode tertentu karena antara kode dan fase melewati ionosfer yang sama lokasinya. Maka dapat diperoleh secara lebih halus (smooth) dengan perata-rataan dalam selang waktu tertentu. Nilai rata-rata perbedaan tersebut pada waktu pengamatan $N$ dapat diperoleh secara rekursif menggunakan persamaan

$$
\begin{aligned}
\Delta T E C_{N} & =\frac{1}{N} \sum_{n=1}^{N} \Delta T E C_{n}=\frac{1}{N} \sum_{n=1}^{N}\left(\operatorname{TEC}_{k, n}-T_{E C_{\Phi, n}}\right) \\
& =\frac{1}{N}\left[\sum_{n=1}^{N-1}\left(\operatorname{TEC}_{k, n}-T E C_{\Phi, n}\right)+\left(T E C_{k, N}-T E C_{\Phi, N}\right)\right]
\end{aligned}
$$

Setelah nilai nilai rata-rata perbedaan tersebut dihitung maka dapat ditambahkan pada persamaan TEC fase untuk mendapatkan TEC kombinasi TEC kode dan TEC fase sebagai berikut

$$
T E C_{S M, N}=T E C_{\Phi, N}+\Delta T E C_{N}
$$

Yang dengan memasukkan persamaan-persamaan yang sesuai dapat disusun kembali menjadi

$$
T E C_{S M, N}=\frac{f_{1}^{2}\left(\lambda_{1} \Phi_{1}-\lambda_{2} \Phi_{2}\right)}{40.3(1-\gamma)}+\frac{1}{N} \sum_{n=1}^{N}\left(\frac{f_{1}^{2}\left[\left(P_{1}-P_{2}\right)+\left(\lambda_{1} \Phi_{1}-\lambda_{2} \Phi_{2}\right)\right]}{40.3(1-\gamma)}\right)+\frac{f_{1}^{2}\left(-B_{i}-B^{P}\right)}{40.3(1-\gamma)}
$$

\subsection{Kalibrasi TEC}

Persamaan (5) hanya untuk satu sinyal yang dipancarkan dari satelit ke penerima. Jika ada pengamatan sinyal satelit dalam periode tertentu yang mana ionosfer dianggap dalam kondisi tetap selama periode pengamatan tersebut maka persamaan (5) dapat dibuat lebih umum sebagai

$$
Y_{i}^{t}=\alpha S T E C_{i}^{t}+C
$$

Yang dalam persamaan tersebut STEC adalah nilai slant TEC sepanjang lintasan sinyal dari satelit ke receiver yang dihitung menggunakan kombinasi data kode dan fase menurut metode 1 (persamaan (10) atau metode 2 (persamaan (13)). 
Sebagaimana terlihat pada persamaan (14), STEC yang dihitung masih mengandung nilai kesalahan $\mathrm{C}$ yang merupakan gabungan dari bias differensial kode pada hardware penerima dan satelit nois pengukuran, dan multipath. Nilai tersebut akan tetap jika tidak ada cycle slip pada pengamatan fase. Maka dengan asumsi bahwa kondisi ionosfer tetap dalam periode tertentu selama pengamatan ionosfer nilai $\mathrm{C}$ dapat diestimasi dengan metode kwadrat terkecil setelah STEC diproyeksikan dalam arah vertikal menurut persamaan

$$
\left(Y_{R}^{S}\right)_{t}=\alpha M(z)\left(V T E C_{R}^{S}\right)_{t}+C
$$

dengan $M(z)=\left[1-\left(\frac{R}{R+H}\right)^{2} \sin ^{2} z\right]^{1 / 2}$

di mana $z$ adalah sudut zenith posisi satelit dari penerima, $R$ jari-jari bumi dan $H$ adalah ketinggian lapisan ionosfer dengan model lapisan tunggal di mana ionosfer diasumsikan sebagai satu lapisan tipis yang terletak pada ketinggian sekitar $350 \mathrm{~km}$.

Setelah nilai C ditentukan berdasarkan persamaan (15) nilai tersebut digunakan untuk koreksi (kalibrasi ) STEC menurut persamaan (14) untuk setiap penerima selama periode tertentu yang dianggap konstan.

\subsection{Pemodelan VTEC regional di atas Wilayah Indonesia}

Setelah didapatkan nilai VTEC yang telah dikalibrasi maka nilai VTEC tersebut menjadi data ionosfer yang dapat digunakan dalam pemodelan VTEC regional di atas wilayah Indonesia menggunakan persamaan

$$
\operatorname{VTEC}(\phi, \lambda)=A+\sum_{n=1}^{N} B_{n} \phi^{n}+\sum_{m=1}^{M} C_{m} \lambda^{m}
$$

di mana $\phi$ dan $\lambda$ adalah lintang dan bujur geografi, $N$ adalah orde fungsi polinom dengan variabel lintang dan $M$ adalah orde fungsi polinom dengan variabel bujur. $N$ dan $M$ dapat ditentukan berdasarkan ktriteria rata-rata kesalahan mutlak yang terkecil antara model dengan data pengamatan.

Koefisien-koefisien $A, B$ dan $C$ tersebut dihitung untuk jam tertentu mulai jam 00.00 UT sampai jam 23.00 UT. Selanjutnya koefisien-koefisien tersebut diestimasi sebagai fungsi waktu UT menggunakan ekspansi Fourier orde 6 yang dapat dituliskan sebagai berikut 


$$
\begin{aligned}
& A(t)=A_{0}+\sum_{n=1}^{6}\left(A_{1 n} \cos \frac{2 \pi n t}{24}+A_{2 n} \sin \frac{2 \pi n t}{24}\right) \\
& B_{p n}(T)=B_{0 p n}+\sum_{n=1}^{6}\left(B_{1 p n} \cos \frac{2 \pi n t}{24}+B_{2 p n} \sin \frac{2 \pi n t}{24}\right) \\
& C_{p n}(t)=C_{0 p n}+\sum_{n=1}^{n}\left(C_{1 p n} \cos \frac{2 \pi n t}{24}+C_{2 p n} \sin \frac{2 \pi n t}{24}\right)
\end{aligned}
$$

dengan indek $p$ adalah untuk koefisien orde model polinom pada persamaan (16) dan $n$ adalah orde deret Fourier.

\section{Hasil dan Pembahasan}

\subsection{Perhitungan TEC dari data kode, fase dan kombinasinya}

Telah dilakukan perhitungan TEC ionosfer dari data kode yang diperoleh dari data GPS stasiun tetap di Indonesia dan sekitarnya. TEC yang telah dihitung tersebut belum dikalibrasi dari kesalahan sistematis, dan masih mengandung bias resdiual. Sehingga dapat dilihat masih terdapat nilai TEC negatif sebagaimana dapat dilihat pada Gambar 2 untuk data GPS stasiun tetap COCO, Gambar 3 dari stasiun DARW yang mana perhitungan TEC kode tersebut belum memperhitungkan pembatasan sudut elevasi. Nilai TEC negatif tersebut terutama terjadi pada waktu-waktu tengah malam sampai menjelang terbit matahari, di mana nilai TEC mencapai nilai minimumnya. Dengan pembatasan sudut elevasi sebesar 30 derajat hasil perhitungan TEC ditunjukkan pada Gambar 4, dengan TEC terbesar hasil perhitungan sekitar 140 TECU, berbeda dengan TEC maksimum tanpa pembatasan sudut elevasi yang menghasilkan TEC terbesar lebih dari 250 TECU.

Dengan kombinasi data kode dan fase metode pertama sebagaimana persamaan (10) dapat ditentukan nilai TEC seperti diperlihatkan pada Gambar 5, yang menunjukkan adanya perbedaan secara jelas dengan TEC dari kode saja, di mana TEC hasil kombinasi data kode dan fase lebih halus dari pada TEC dari kode. Tetapi nilai TEC kombinasi tetap masih tergantung pada nilai awal TEC yang dambil dari data TEC kode. Hal ini menimbulkan penyimpangan yang cukup besar jika nilai TEC awal sudah mengandung kesalahan yang besar berupa penyimpangan TEC kombinasi pada waktu-waktu berikutnya. Dengan kombinasi metode ke 2 (persamaan (13)), hasil perhitungan TEC diperlihatkan pada Gambar 6. Dari Gambar 5 dan 6 diketahui bahwa perbandingan TEC kombinasi metode pertama dan kedua adalah bahwa motode kedua lebih baik dari metode pertama karena dapat menghasilkan TEC yang lebih halus dan nilainya berada dalam daerah rata-rata TEC kode. 
STEC kode 31 Oktober 2003, coco

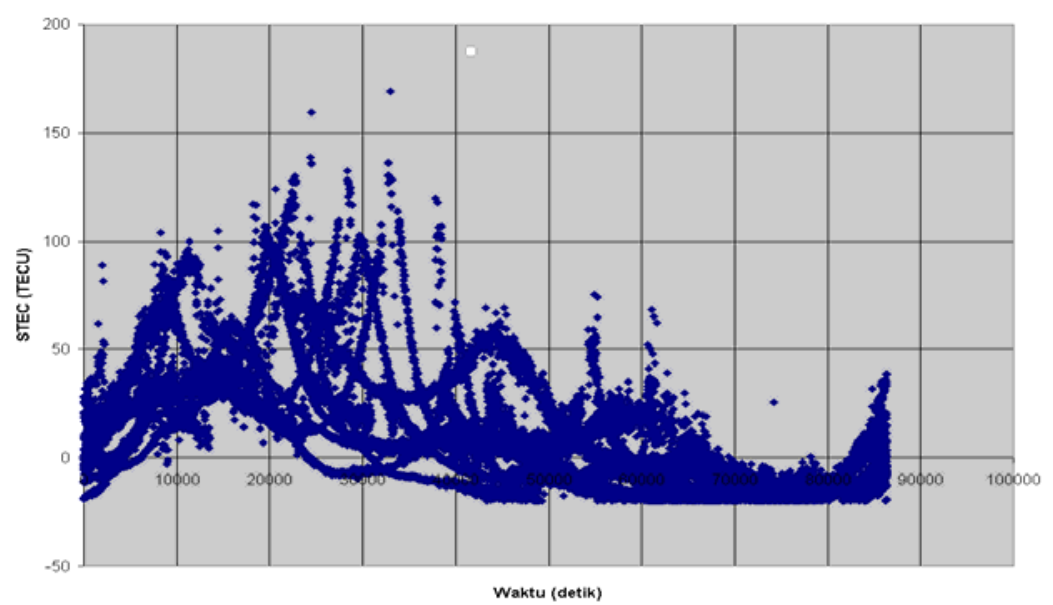

Gambar 2 Slan TEC dari pengamatan GPS stasiun Cocos Island pada tanggal 31 Oktober 2003 tanpa cut off sudut elevasi.

STECk 31 Oktober 2003, DARW

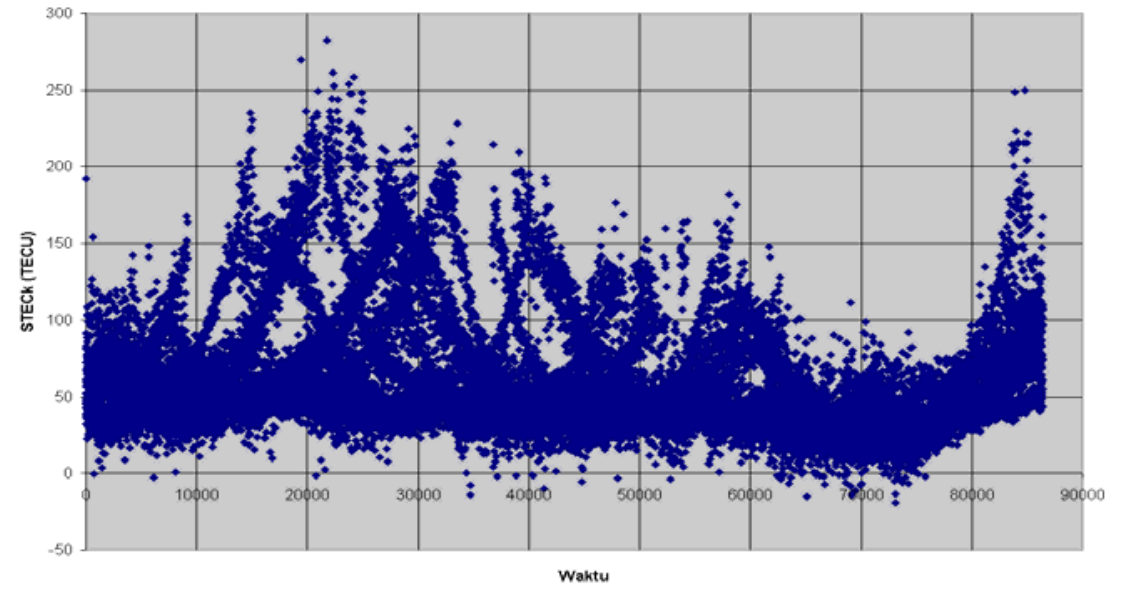

Gambar 3 Slan TEC dari pengamatan GPS stasiun Darwin pada tanggal 31 Oktober 2003 tanpa cut off sudut elevasi. 


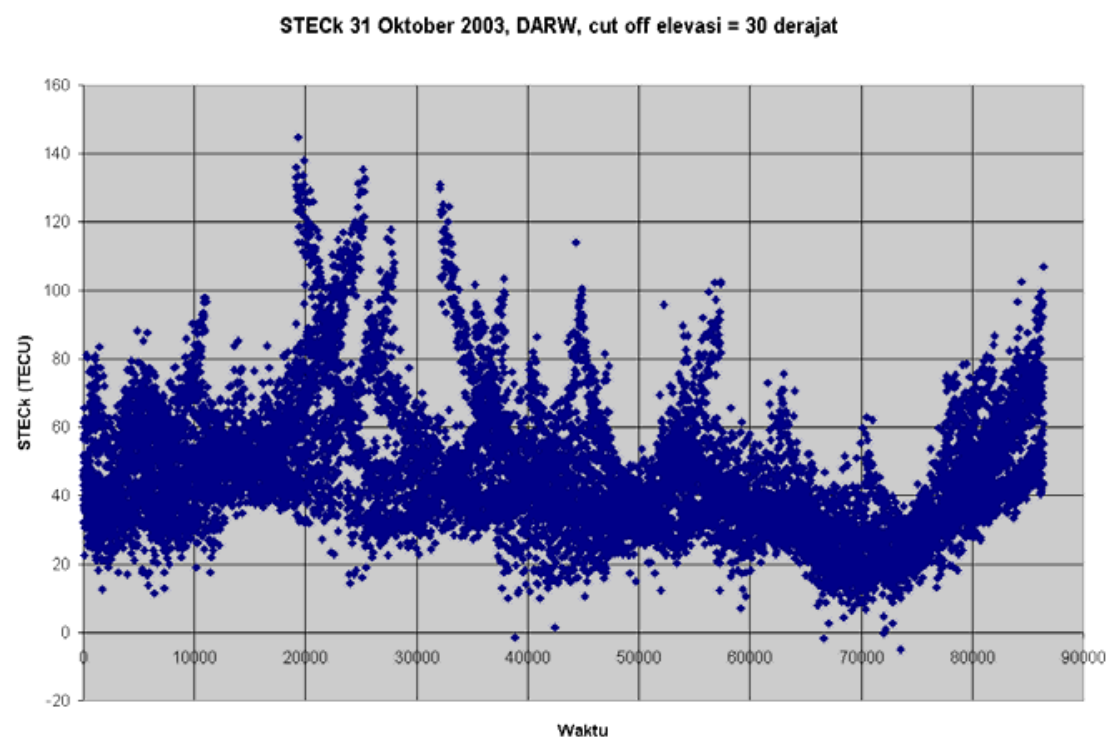

Gambar 4 Slan TEC dari pengamatan GPS stasiun Darwin pada tanggal 31 Oktober 2003 dengan cut off sudut elevasi $30^{\circ}$.

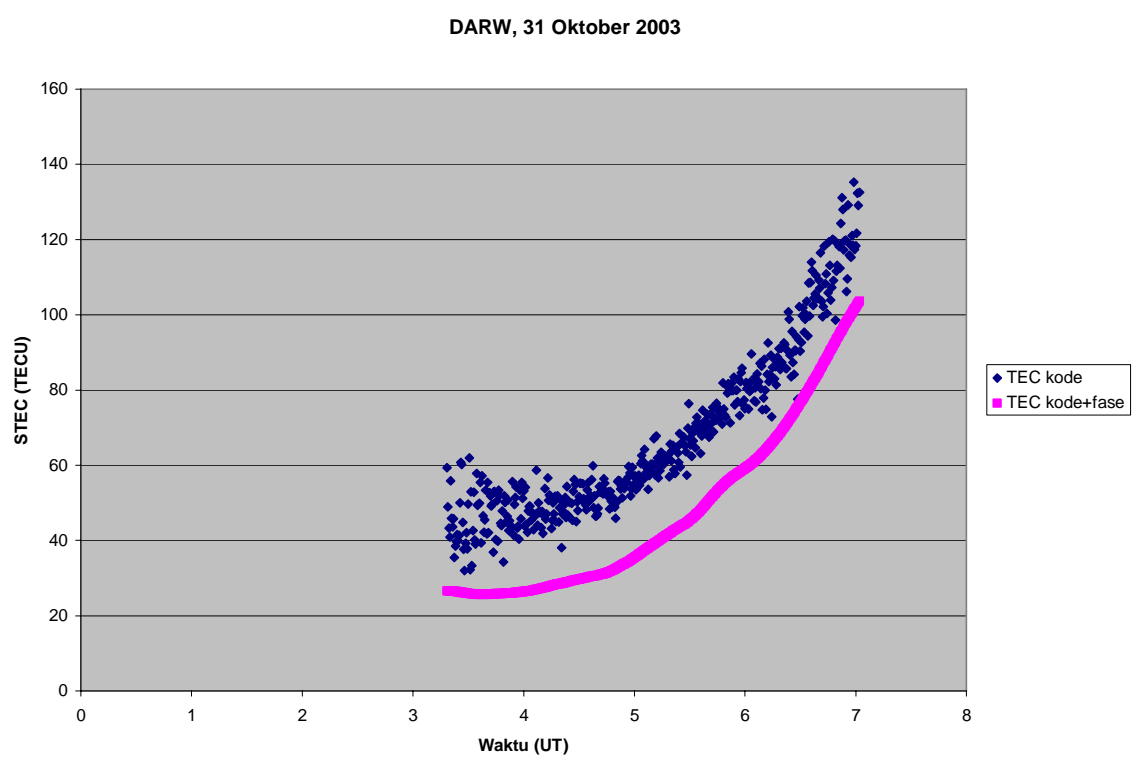

Gambar 5 Slan TEC dari pengamatan GPS stasiun Darwin pada tanggal 31 Oktober 2003 yang dihitung dari data kode (titik-titik) dan kombinasi kode dan fase (garis lurus) metode 1. 


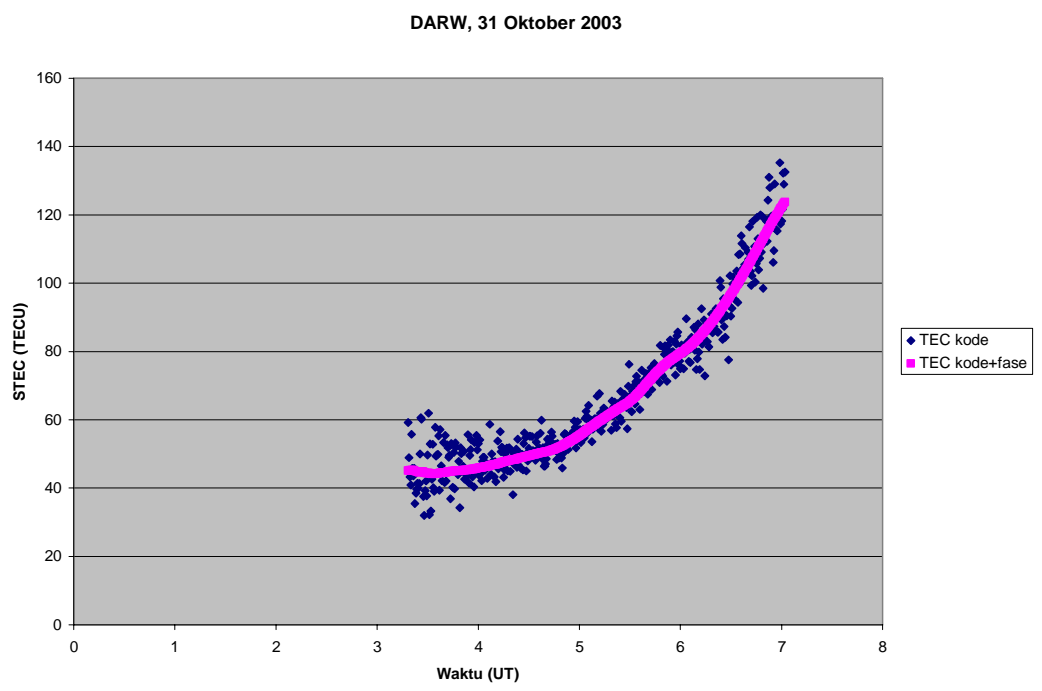

Gambar 6 Slan TEC dari pengamatan GPS stasiun Darwin pada tanggal 31 Oktober 2003 yang dihitung dari data kode (titik-titik) dan kombinasi kode dan fase (garis lurus) metode 2.

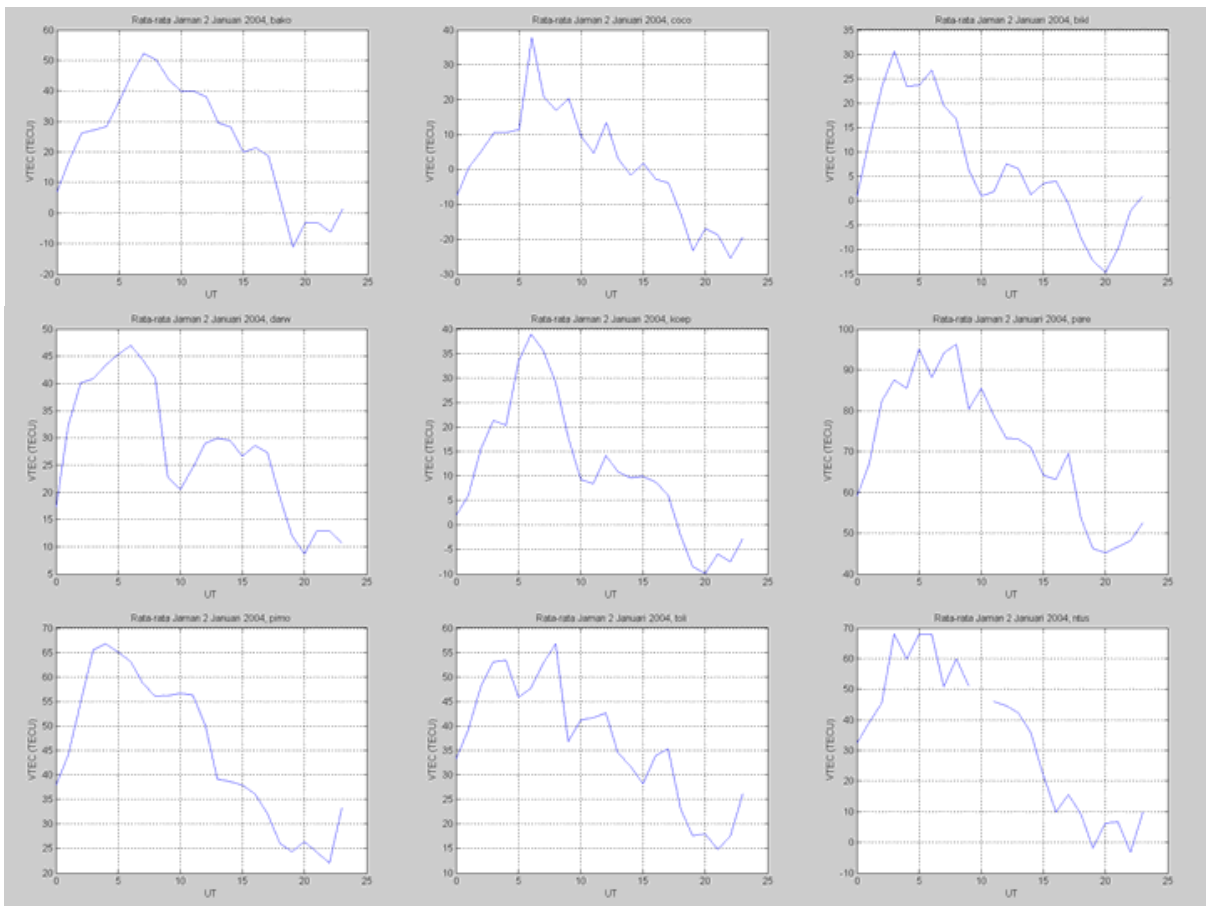

Gambar 7 Rata-rata jaman STEC kode dari pengamatan GPS stasiun tetap di Indonesia dan sekitarnya dengan sudut elevasi di atas $45^{\circ}$. 


\subsection{Nilai absolut TEC dari data kode.}

Dari Gambar 7 diketahui bahwa nilai TEC dari data kode GPS mengandung nilai negatif untuk beberapa stasiun pengamat GPS dan ada yang relatif tinggi untuk beberapa stasiun pengamat yang lain. Hal ini menunjukkan bahwa nilai TEC masih mengandung kesalahan yang bersumber dari bias instrumental penerima dan satelit, bias multipath, dan nois yang keeluruhannya bisa disebut sebagai bias residual. Maka dari itu nilai TEC tersebut perlu dikalibrasi untuk mengeliminasi kesalahan-kesalahan yang ada. Salah satu cara untuk mengkalibrasi TEC tersebut adalah dengan mengeliminasi bias residual (interfrekuensi hardware (penerima dan satelit), multipath, noise dll) dengan menggunakan kwadrat terkecil dari persamaan (15), dengan asumsi selama periode pengamatan nilai TEC dianggap konstan sehingga diperoleh pengamatan sinyal GPS yang melintasi ionosfer yang ditinjau yang dianggap kondisi ionosfernya tetap.

\subsection{Kalibrasi TEC}

Kalibrasi TEC dapat dilakukan dengan menghitung C pada persamaan (15). Dengan menggunakan data 3 bulan mulai Januari - Maret 2004 dan dengan periode pengatan setiap $1 \frac{1}{2}$ jam telah diperoleh nilai C sebagai koreksi terhadap nilai TEC sebagaimana dapat dilihat pada Gambar 8. Kriteria penentuan bias residual adalah kenyataan bahwa VTEC harus bernilai positif dan nilainya kurang dari 100 TECU dan dipilih nilai bias residual yang tingkat kepercayaannya di atas $90 \%$ dalam estimasinya menggunakan kwadrat terkecil. Selain itu data STEC yang digunakan untuk kalibrasi juga dipilih pada sudut elevasi lebih besar dari 70 derajat untuk mereduksi efek multipath pada persamaan (6).

Bias Residual (IFB, multipath, noise dII).

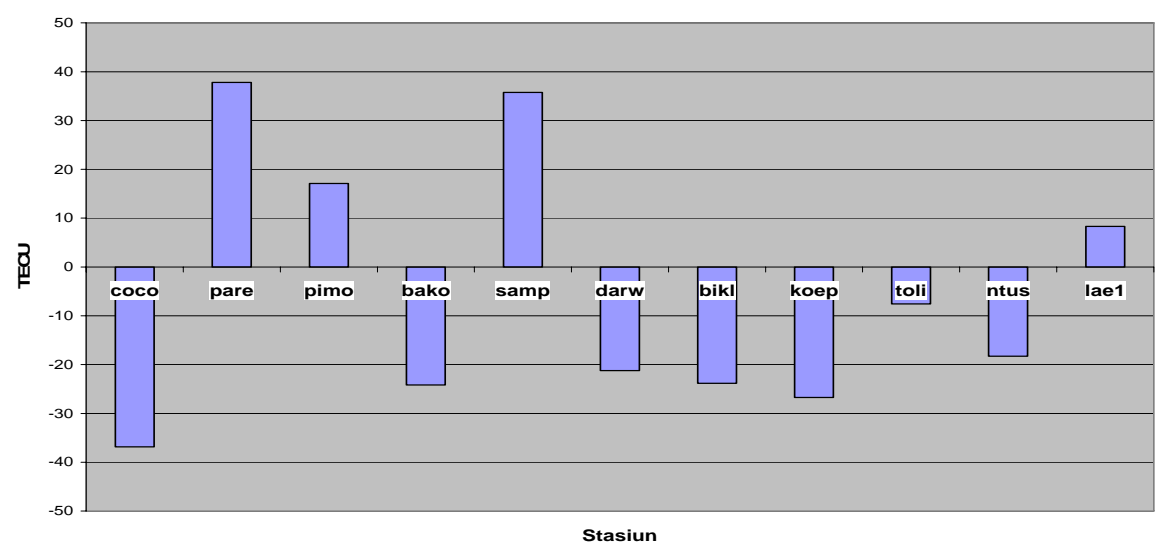

Gambar 8 Bias residual yang dihitung dari rata-rata harian bias residual setiap penerima di Indonesia dan sekitarnya. 
Berdasarkan nilai koreksi tersebut nilai STEC harus ditambah (untuk C negatif) atau dikurangi (untuk C positif). Kemudian nilai VTEC dihitung dari nilai STEC yang telah dikalibrasi. Untuk stasiun Cocos Island (сосо) nilai VTEC sebelum dan sesudah kalibrasi ditunjukkan pada Gambar 9 dan untuk stasiun BAKO (Cibinong) ditunjukkan pada Gambar 10.

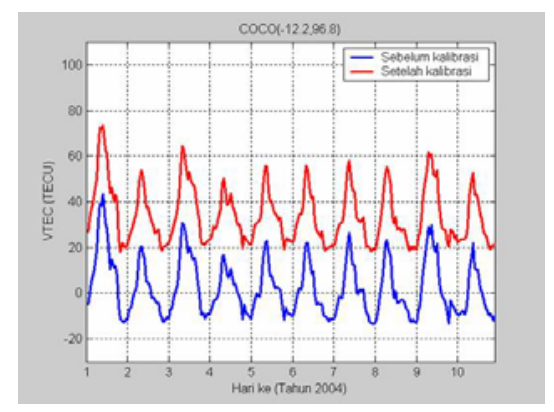

Gambar 9 VTEC sebelum dikalibrasi (yang mengandung nilai negatif, grafik bagian bawah) dan sesudah kalibrasi (grafik bagian atas).

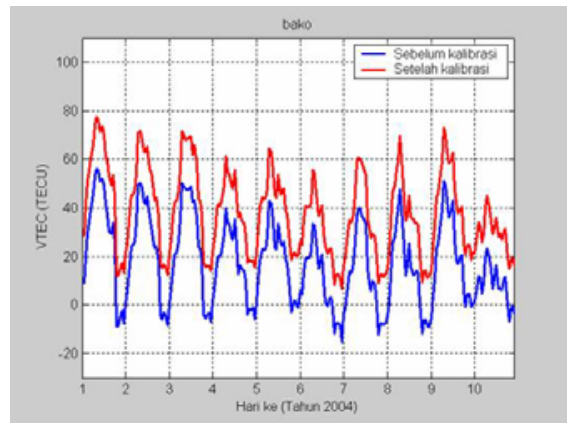

Gambar 10 VTEC sebelum dan sesudah kalibrasi.

\subsection{Pemodelan VTEC di atas Indonesia}

Model VTEC diperlukan untuk koreksi ionosfer dalam penentuan posisi metode absolute menggunakan GPS frekuensi tunggal. Jika telah diperoleh data pengukuran GPS frekuensi tunggal di suatu tempat dan tidak ada data GPS yang berdekatan sehingga tidak memungkinkan untuk koreksi ionosfer secara differensial maka diperlukan model ionosfer. Menggunakan formulasi pada persamaan (16) dan (17) telah diperoleh model VTEC regional di atas Indonesia dari 11 stasiun pengamat GPS seperti terlihat pada Tabel 1. Untuk tanggal 2 Januari 2004 model VTEC jam 0, 5, 8 dan 11 UT dapat dilihat pada Gambar 11. Dari gambar tersebut dapat diketahui bahwa variasi spasial VTEC telah dapat menunjukkan adanya anomali ionisasi terutama pada jam 8 UT (12 LT) dan 11 UT (18 LT). Variasi temporal juga dapat direpresentasikan oleh model. Dengan model tersbeut kita dapat menghitung STEC dari model VTEC jika kita punya 
data koordinat satelit yang selanjutnya dapat digunakan untuk koreksi bias ionosfer pada pengukuran GPS dengan frekuensi tunggal L1.
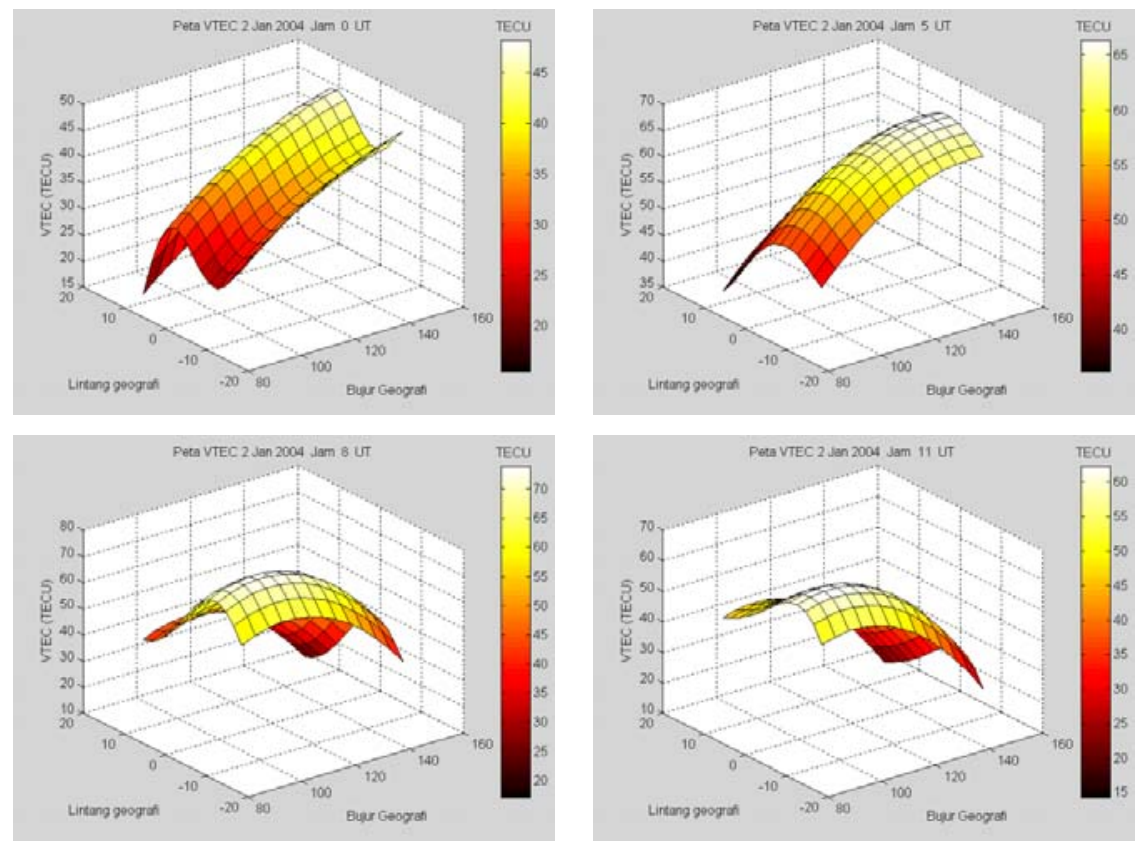

Gambar 11 Model VTEC di atas Indonesia 2 Januari 2004.

\section{$4 \quad$ Kesimpulan dan Kegiatan Lanjut}

Nilai TEC hasil perhitungan dari data kode untuk setiap penerima masih mengandung bias residual yang perlu diestimasi. Bias residual dapat diestimasi menggunakan metode kwadrat terkecil pada selang waktu pengamatan tertentu dengan asumsi dalam selang waktu tersebut kondisi ionosfer dianggap tetap dalam area yang teramati dari sinyal satelit GPS yang bergerak. Setelah dikoreksi dengan bias residual nilai VTEC selalu positif untuk semua stasiun pengamatan yang digunakan untuk penentuan TEC.

Kombinasi data kode dan fase dengan metode perhitungan rata-rata perbedaan antara TEC kode dan TEC fase dapat menghasilkan TEC yang lebih akurat dari pada metode kombinasi dengan mengambil nilai awal dari TEC kode.

Model TEC regional dari data GPS di Indonesia dan sekitarnya telah dapat dibuat menggunakan fungsi polinom orde 5 untuk ketergantungan ionosfer terhadap lintang dan orde 2 untuk ketergantungan terhadap bujur serta dengan deret Fourier orde 6 untuk variasi ionosfer terhadap variasi diurnal. 
Model TEC regional ini masih perlu divalidasi menggunakan nilai TEC hasil pengamatan ionosonde atau dari model yang sudah ada. Hal itu merupakan kegiatan lanjutan dari penelitian ini.

\section{Daftar Rujukan}

1. El-Arini, M.B., Hegarty, C.J., Fernow, J.P. \& Klobuchar, J.A., Development of an Error Budget for a GPS Wide-Area Augmentation System (WAAS), Proceedings of The Institute of Navigation National Technical Meeting, San Diego, CA, January, 1994.

2. Gao, Y., Liu, Z.Z., Precise ionospehric modeling using regional GPS network data, Journal of Global Positioning System, Vol. 1.No. 1: 18-24 (2002).

3. Klobuchar, J.A., Ionospheric Time-Delay Algorithm for SingleFrequency GPS Users, IEEE Transactions on Aerospace and Electronic Systems, Vol. AES-23, No.3, pp.325-331 (1987).

4. Liu Zhizhao, Ionospheric modeling and applications using Global Positioning System (GPS) measurements, PhD. Thesis, University of Calgary, Calgary, Alberta (2004). 